\title{
Neuronal Proteoglycans: Biosynthesis and Functional Interaction with Neurons in vitro
}

\author{
Kimberly E. Dow, ${ }^{1}$ S. E. L. Mirski, ${ }^{2}$ J. C. Roder, ${ }^{3}$ and R. J. Riopelle ${ }^{4}$ \\ Departments of ${ }^{1}$ Pediatrics (Neonatology) and ${ }^{2}$ Microbiology and Immunology, Queen's University, Kingston, ${ }^{3}$ Mount Sinai \\ Research Institute, Toronto, and ${ }^{4}$ Department of Medicine (Neurology), Queen's University, Kingston, Ontario K7L 3N6, \\ Canada
}

\begin{abstract}
Glycosaminoglycans (GAGs) with electrophoretic mobilities on cellulose acetate similar to heparin $(\mathrm{H})$, heparan sulfate (HS), and chondroitin sulfate (CS) were detected in cell extracts and in conditioned medium of high-density, neuronenriched cultures labeled with ${ }^{35} \mathrm{SO}_{4}$. Heparitinase digestion revealed that heparan sulfate proteoglycans (HSPGs) were heterogeneous in charge density and were responsible for neurite outgrowth activity for sensory neurons in conditioned medium. In the presence of $\beta$-D-xyloside, an inhibitor of proteoglycan assembly, there was an increase of released GAGs with the mobility of CS and heavily sulfated HS but a decrease in neurite outgrowth activity on a laminin substrate at times greater than $14 \mathrm{hr}$.
\end{abstract}

In the presence of $\beta$-D-xyloside or the monoclonal antibody HNK-1 (Leu 7), which recognizes a neuronal cell surface epitope, there was a time-dependent inhibition of process formation that was half-maximal at 7-8 $\mathrm{hr}$ and independent of laminin concentration or cell adhesion to the laminin substrate. The kinetics and magnitude of the inhibitory effects of $\beta$-D-xyloside and HNK-1 (Leu 7) were similar, and the influence of HNK-1 (Leu 7) could no longer be observed in the presence of $\beta-\mathrm{D}-\mathrm{xyloside}$. Pretreatment of the laminin substrate with conditioned medium from high-density neuron cultures resulted in an increased rate of neurite formation compared with untreated laminin. Where the laminin substrate had been pretreated with conditioned medium, maximal inhibition by HNK-1 (Leu 7) was apparent from the earliest times. However, if the conditioned medium had been digested with heparitinase, neither enhanced neurite outgrowth nor the inhibitory influence of HNK-1 (Leu 7) were observed.

The present biosynthetic and functional studies suggest that neurons are one source of HSPGs. These data complement and extend earlier studies suggesting a role for HSPGs in neurite formation. The experiments also provide evidence for modulation of laminin by HSPGs which interact with laminin and promote neurite outgrowth that is mediated by a cell surface receptor at or in juxtaposition to the HNK-1 (Leu 7) epitope.

\footnotetext{
Received Aug. 3, 1987; revised Jan. 14, 1988; accepted Feb. 2, 1988.

We wish to thank M. Solc for technical assistance and D. Randle for typing the manuscript. Supported by the Hospital for Sick Children Foundation Grant 8648, the Canadian Paraplegic Association, the Medical Research Council of Canada, and the Multiple Sclerosis Society of Canada (for a fellowship to S.M.).

Correspondence should be addressed to Dr. R. J. Riopelle, Queen's University, $\%$ Kingston General Hospital, Kingston, Ontario, K7I. 2V7, Canada.

Copyright (C) 1988 Society for Neuroscience $0270-6474 / 88 / 093278-12 \$ 02.00 / 0$
}

There is evidence to suggest that the developing nervous system produces several classes of proteoglycans. At various times during ontogeny of the CNS, proteoglycans have been found to be associated with neurons and non-neurons (Margolis et al., 1975; Aquino et al., 1984). Embryonic neurons and PCI2 pheochromocytoma cells maintained in vitro have been shown to display heparan sulfate proteoglycan (HSPG)-likc immunorcactivity (Matthew and Patterson, 1984; Matthew et al., 1985). Heparan sulfate proteoglycans have been implicated in Schwann cell proliferation (Ratner et al., 1985), in neurite extension (Matthew et al., 1985), and in cell-cell and cell-substrate adhesion (Cole and Glaser, 1986; Cole et al., 1986). There is evidence that neural cell adhesion molecules have binding domains for HSPGs (Cunningham et al., 1983; Cole and Glaser, 1986; Cole et al., 1986) and laminin, a major component of basal lamina, is known to have a binding site for this proteoglycan at the globular end of the long arm (Timpl et al., 1983; Edgar et al., 1984; Engvall et al., 1986). HSPG is intimately associated with the basal lamina of the PNS (Eldridge et al., 1986; Carey et al., 1987).

In previous studies it has been found that embryonic cultures highly enriched for sensory or central neurons release to their environment molecular species that become substrate bound and promote neurite outgrowth (Riopelle et al., 1986). Since proteoglycans bound to laminin (Timpl et al., 1983; Engvall et al., 1986) are believed to play a role in neurite extension (Lander et al., 1985), the present study was designed to determine if neuron-conditioned medium contained proteoglycans, to characterize cell-bound and released proteoglycans synthesized by neurons in vitro, and to identify those proteoglycans with neurite-promoting activity when bound to laminin.

The monoclonal antibody HNK-1 (Leu 7), which recognizes a carbohydrate epitope on a family of nervous system cell surface adhesion glycoproteins (Kruse et al., 1984; McGarry et al., 1985) and interferes with neurite formation on a poly(D-lysine) substrate treated with neuron-conditioned medium (Riopelle et al., 1986), has permitted an examination of the role of cell surface carbohydrate epitopes in the interaction of sensory neurons with the proteoglycan-laminin complex.

\section{Materials and Methods}

Materials. Tissue culture medium and fetal calf serum were obtained from Gibco. Trypsin and DNAse were from Worthington. Nerve growth factor (NGF) was prepared as described by Mobley et al. (1976) and Chapman et al. (1981). Additives to prepare defined medium as described by Bottenstein et al. (1980) (insulin, progesterone, transferrin, selenium, putrescine), cytosine arabinoside, poly(D-lysine), anti-rabbit IgG peroxidase conjugate, dimethylthiazol-2-yl-2,5-diphenyltetrazolium bromide (MTT), papain, $p$-nitrophenyl- $\beta$-D-xylopyranoside, 
4-methylumbelliferyl- $\beta$-D-glucoside, glycosaminoglycan reference standards, and chondroitinase $\mathrm{ABC}$ were from Sigma. Heparitinase was purchased from ICN. Rabbit anti-chick neurofilament (NF160) antiserum was a gift of $G$. Bennett (University of Pennsylvania); rabbit antigalactocerebroside was a gift of R. Lisak (University of Pennsylvania); rabbit antiglial fibrillary acidic protein (GFAP) was from Amersham; and rabbit immunoglobulin was from Cedarlane. Alkaline phosphataseconjugated goat anti-rabbit immunoglobulins and substrates were purchased from Promega. L-4,5- ${ }^{3} \mathrm{H}$-leucine and ${ }^{35} \mathrm{~S}$-sulfate were from New England Nuclear. Laminin was from Bethesda Research Laboratories or a gift from S. Carbonetto (McGill University). Rabbit antilaminin and rabbit antifibronectin were from Bethesda Research Laboratories. The monoclonal antibody HNK-1 (Leu 7) was prepared as ascites fluid. Control ascites fluid (P3X) was prepared by intraperitoneal injection of the P3X cell line-the fusion partner for HNK-1 (Leu 7) monoclonal antibody production. Ascites-prepared monoclonal antibodies GENS1, GEN-S3, and GEN-S8, which recognize peptide fragments of the cell adhesion molecule myelin-associated glycoprotein $(M \wedge G)$ (NobileOrazio et al., 1984) were gifts of N. Latov. The monoclonal antibodies in ascites fluid were not further purified and were stored at $20 \mathrm{mg} / \mathrm{ml}$ at $-70^{\circ} \mathrm{C}$

Cell culture for production of conditioned medium. Spinal cords were removed from $8 \mathrm{~d}$ chick embryos, chopped, and incubated in $0.1 \%$ trypsin in $0.05 \mathrm{mg} / \mathrm{ml}$ DNAse in $\mathrm{Ca}^{2+} / \mathrm{Mg}^{2+}$-free Gey's balanced salt solution (CMF) for $30 \mathrm{~min}$ at $37^{\circ} \mathrm{C}$. The reaction was stopped by removing the incubation solution and adding defined medium (Bottenstein et al., 1980) with $10 \%$ fetal calf serum (FCS). Following trituration, the cell suspension was centrifuged $\left(750 \times g\right.$ for $8 \mathrm{~min}$ at $\left.4^{\circ} \mathrm{C}\right)$ through a concentrated FCS gradient, suspended in defined medium with FCS, plated on a $100 \mathrm{~mm}$ Falcon culture dish in $4 \mathrm{ml}$ of medium, and incubated for $2 \mathrm{hr}$ at $37^{\circ} \mathrm{C}, 5 \% \mathrm{CO}_{2}$. The nonadherent, neuron-enriched population of cells was then seeded into $18 \mathrm{~mm}$ wells coated with poly(Dlysine) $(0.1 \mathrm{mg} / \mathrm{ml}$ for $24 \mathrm{hr})$ at a plating density of $10^{5}$ cells per well in defined medium with $10 \%$ FCS. After $24 \mathrm{hr}$ incubation at $37^{\circ} \mathrm{C}, 5 \%$ $\mathrm{CO}_{2}$, the medium was removed, the wells washed and replenished with serum-free defined medium with $10 \mu \mathrm{M}$ cytosine arabinoside. After $6 \mathrm{~d}$ the medium conditioned by the cells was removed, filtered through 0.2 $\mu \mathrm{m}$ Millipore filters and kept at $4^{\circ} \mathrm{C}$. Cells were fixed and processed subsequently for immunocytochemistry or were removed from wells with CMF $(0.5 \mathrm{ml} /$ well $)$ and kept for glycosaminoglycan isolation. Protein content of the conditioning cells was measured by the method of Lowry et al. (1951).

Sensory neurons, obtained from dorsal root ganglia (DRG), were prepared as described for spinal cord cultures with the following exceptions: $0.01 \%$ trypsin for $10 \mathrm{~min}$ was used, and cultures were established in supplemented Ham's F12 medium with $5 \%$ FCS (Sutter et al., 1979) with 4 pM NGF for $24 \mathrm{hr}$. The medium was then changed to serumfree defined medium with 4 pM NGF and $10 \mu \mathrm{M}$ cytosine arabinoside.

Radioisotope labeling of cultures. After $24 \mathrm{hr}$ in serum-free defined medium with cytosine arabinoside, cultures were labeled with ${ }^{35} \mathrm{~S}$-sulfate $(20 \mu \mathrm{Ci} / \mathrm{ml})$ in the same medium or $\mathrm{L}-4,5-{ }^{3} \mathrm{H}$-leucine $(10 \mu \mathrm{Ci} / \mathrm{ml})$ in serum-free, leucine-free defined medium. In some experiments, $p$-nitrophenyl- $\beta$-D-xylopyranoside ( $\beta$-D-xyloside) was added to culture wells at a concentration of $1.0 \mathrm{~mm}$ at the time neurons were seeded.

Immunocytochemistry. Immunocytochemical labeling of conditioning cells was performed after $7 \mathrm{~d}$ in culture following light fixation with $2 \%$ paraformaldehyde for $5-10 \mathrm{~min}$, washing in Tris-buffered saline and TWEEN 20 (TBST; $10 \mathrm{~mm}$ Tris-HCl, pH 8.0, $150 \mathrm{~mm} \mathrm{NaCl}, 0.05 \%$ TWEEN 20), and blocking for 30 min with TBST and 1\% BSA. Rabbit anti-chick neurofilament (NF160) (Bennett et al., 1984), rabbit antiGAL-C (to identify oligodendrocytes; McGarry et al., 1985), rabbit antiGFAP (to identify astrocytes; McGarry et al., 1985), or rabbit immunoglobulin as control were incubated with the cells at a dilution of 1:200 for $45 \mathrm{~min}$ at $25^{\circ} \mathrm{C}$. The wells were washed thoroughly and then incubated with anti-rabbit IgG peroxidase conjugate $(1: 250)$. After thorough washing the cells were overlaid with $0.05 \mathrm{M}$ Tris- $\mathrm{HCl}$ (pH 7.6) containing diaminobenzidine $0.5 \mathrm{mg} / \mathrm{ml}$ and $0.009 \% \mathrm{H}_{2} \mathrm{O}_{2}$ for $15 \mathrm{~min}$. The reaction was stopped by washing with $0.05 \mathrm{M}$ Tris- $\mathrm{HCl}$, and the cells were photographed with bright-field optics using a Leitz Diavert microscope with camera attachment.

Sensory neurons, prepared as described and seeded on Terasaki plate wells, were incubated for $24 \mathrm{hr}$ and then treated as follows: the neurons were lightly fixed with $2 \%$ paraformaldehyde for 5-10 min; plates were washed in TBST three times for 5 min cach at room tcmpcrature and then blocked for 30 min with TBST and 1\% BSA. The GEN-S3 and
HNK-1 (Leu 7) monoclonal antibodies were used at dilutions of 1:40 in TBST buffer for $30 \mathrm{~min}$, followed by three $10 \mathrm{~min}$ washes in TBST; the wells were then reacted with 1:1500-1:4500 alkaline phosphatase conjugated goat anti-mouse immunoglobulins in TBST for $30 \mathrm{~min}$, followed by 3 TBST washes. The color reaction was developed with the substrate nitroblue tetrazolium and 5-bromo,4-chloro,3-indolyl phosphate in alkaline phosphatase buffer (100 mM Tris- $\mathrm{HCl}, \mathrm{pH} 9.5,100$ $\mathrm{mM} \mathrm{NaCl}$, and $5 \mathrm{mM} \mathrm{MgCl}_{2}$ ).

Glycosaminoglycan (GAG) isolation and separation. GAGs were isolated from neuron-conditioned medium and from cells after $7 \mathrm{~d}$ in culture by a modification of the method of Hronowski and Anastassiades (1980). Four volumes of ethanol were added to the medium or cell suspension, and the mixture was allowed to stand for $1 \mathrm{hr}$ at $25^{\circ} \mathrm{C}$. The pellet obtained after centrifugation at $10,000 \times g$ for $10 \mathrm{~min}$ was washed with acetone and allowed to stand for $\mathbf{3 0} \mathrm{min}$. After centrifugation as above, the pellet was air-dried overnight and then digested with $1.5 \%$ ( $\mathrm{vol} / \mathrm{vol}$ ) papain ( $1 \mathrm{ml}$ for each $\mathrm{ml}$ of medium or cell suspension) for $24 \mathrm{hr}$ at $65^{\circ} \mathrm{C}$. The papain digest was diluted with 2.5 volumes distilled water, and $0.1 \mathrm{ml}$ of $5 \%$ cetylpyridinium chloride (CPC) in $0.2 \mathrm{M} \mathrm{Na}_{2} \mathrm{SO}_{4}$ was added per milliliter of undiluted papain digest. After $1 \mathrm{hr}$ at $37^{\circ} \mathrm{C}$ the precipitate was collected by centrifugation for $10 \mathrm{~min}$ at $15,000 \times$ $g$. The pellet was dissolved in $2 \mathrm{ml} 2 \mathrm{M}$ sodium acetate-ethanol (100: $15, \mathrm{vol} / \mathrm{vol}$ ), $\mathrm{pH} 7.0$, and incubated for $30 \mathrm{~min}$ at $37^{\circ} \mathrm{C}$. Six volumes of ethanol were added, and the GAGs were allowed to precipitate overnight at $4^{\circ} \mathrm{C}$. The pellet collected after centrifugation $(15,000 \times g$ for $10 \mathrm{~min})$ was washed with distilled water and the samples lyophilized.

GAG isolates were separated by a modification of the method of Capelletti et al. (1979). The isolates were redissolved in 10-20 $\mu \mathrm{l}$ of distilled water, applied to Titan ZipZone cellulose acetate plates and electrophoresed (180 V for $7 \mathrm{~min}$ ) in a LKB 2117 flat-bed apparatus with $1.0 \mathrm{M}$ barium acetate, $\mathrm{pH} 5.0$, as running buffer. The plates were soaked in $0.1 \mathrm{M}$ barium acetate, $\mathrm{pH} 5.0$, for $2 \mathrm{~min}$; electrophoresed at $200 \mathrm{~V}$ for $20 \mathrm{~min}$; soaked in $0.1 \mathrm{M}$ barium acetate, $\mathrm{pH} 5.0$, with $15 \%$ ethanol for $2 \mathrm{~min}$; and then subjected to $200 \mathrm{~V}$ for $25 \mathrm{~min}$. The plates were stained with $0.1 \%$ Alcian blue in $10 \%$ ethanol, $0.1 \%$ acetic acid, and $0.03 \mathrm{M} \mathrm{MgCl}_{2}$ for $30 \mathrm{~min}$, destained in the same solution without Alcian blue, scraped for scintillation counting, or subjected to radioautography at $-70^{\circ} \mathrm{C}$ (Bonner and Laskey, 1974). GAGs were identified by their electrophoretic mobility relative to a mixture of reference standards $(1 \mathrm{mg} / \mathrm{ml})$-heparin, from porcine intestinal mucosa; heparan sulfate, from bovine kidney; and chondroitin sulfate, from shark cartilage.

$C P C$ filter assay. ${ }^{35} \mathrm{~S}$-sulfate-labeled materials were also analyzed by the method of Rapraeger and Bernfield (1985). Aliquots of conditioned medium were spotted onto dry Whatman $3 \mathrm{MM}$ filter disks previously soaked in $2.5 \%$ CPC. The disks were washed in distilled water and then soaked in $25 \mathrm{~mm}$ sodium sulfate for $1 \mathrm{hr}$, followed by $1 \mathrm{hr}$ in distilled water. These washes remove free ${ }^{35} \mathrm{~S}$-sulfate but do not affect GAGcontaining materials. After washing in $95 \%$ ethanol, the disks were dried for scintillation counting.

Enzyme digestions. Enzymatic digestions were carried out on isolated GAGs prior to electrophoresis or on conditioned medium prior to the $C P C$ filter assay or bioassay. Chondroitinase $A B C$ was used at $100 \mathrm{mU} /$ $\mathrm{ml}$ in $\mathrm{CMF}, \mathrm{pH} 7.4$, for $1 \mathrm{hr}$ at $37^{\circ} \mathrm{C}$, and heparitinase $(350 \mathrm{mU} / \mathrm{ml}$ in $50 \mathrm{~mm}$ Tris, $5 \mathrm{~mm}$ calcium acetate, $\mathrm{pH} 7.0$ ) was incubated with the samples for $1 \mathrm{hr}$ at $43^{\circ} \mathrm{C}$. Controls consisted of isolated GAGs or conditioned medium incubated in buffer only. For the bioassay, another control consisted of conditioned medium containing heparitinase or chondroitinase placed on a laminin substrate overnight at $4^{\circ} \mathrm{C}$. Concentrations of enzymes used were chosen on the basis of specific effects on chondroitin sulfate and heparan sulfate standards.

Electrophoresis. Dialyzed, lyophilized samples of ${ }^{3} \mathrm{H}$-leucine and ${ }^{35} \mathrm{~S}-$ sulfate-labeled conditioned media were subjected to SDS-PAGE by the method of Laemmli (1970). Separating gels were 5-25\% linear acrylamide gradients and stacking gels were $5 \%$ acrylamide. Labeled material was detected by fluorography at $-70^{\circ} \mathrm{C}$.

Inverted plate bioassay. Sensory neurons were prepared as described, and neurons were seeded into wells of Terasaki microculture plates at a plating density of 500-900 cells/well in defined medium (Bottenstein et al., 1980) with 4 pM NGF. The wells had been treated overnight $\left(37^{\circ} \mathrm{C}, 5 \% \mathrm{CO}_{2}\right)$ with poly(D-lysine) $(0.1 \mathrm{mg} / \mathrm{ml})$, washed extensively, treated overnight $\left(37^{\circ} \mathrm{C}, 5 \% \mathrm{CO}_{2}\right)$ with laminin $(1-100 \mu \mathrm{g} / \mathrm{ml})$, and washed thoroughly. In some experiments, $\beta$-D-xyloside or 4-methylumbelliferyl- $\beta$-D-glucoside (0.2-2 mM) (Carey et al., 1987), monoclonal antibodies HNK-1 (Leu 7), GEN-S1, GEN-S3, and GEN-S8, and poly- 

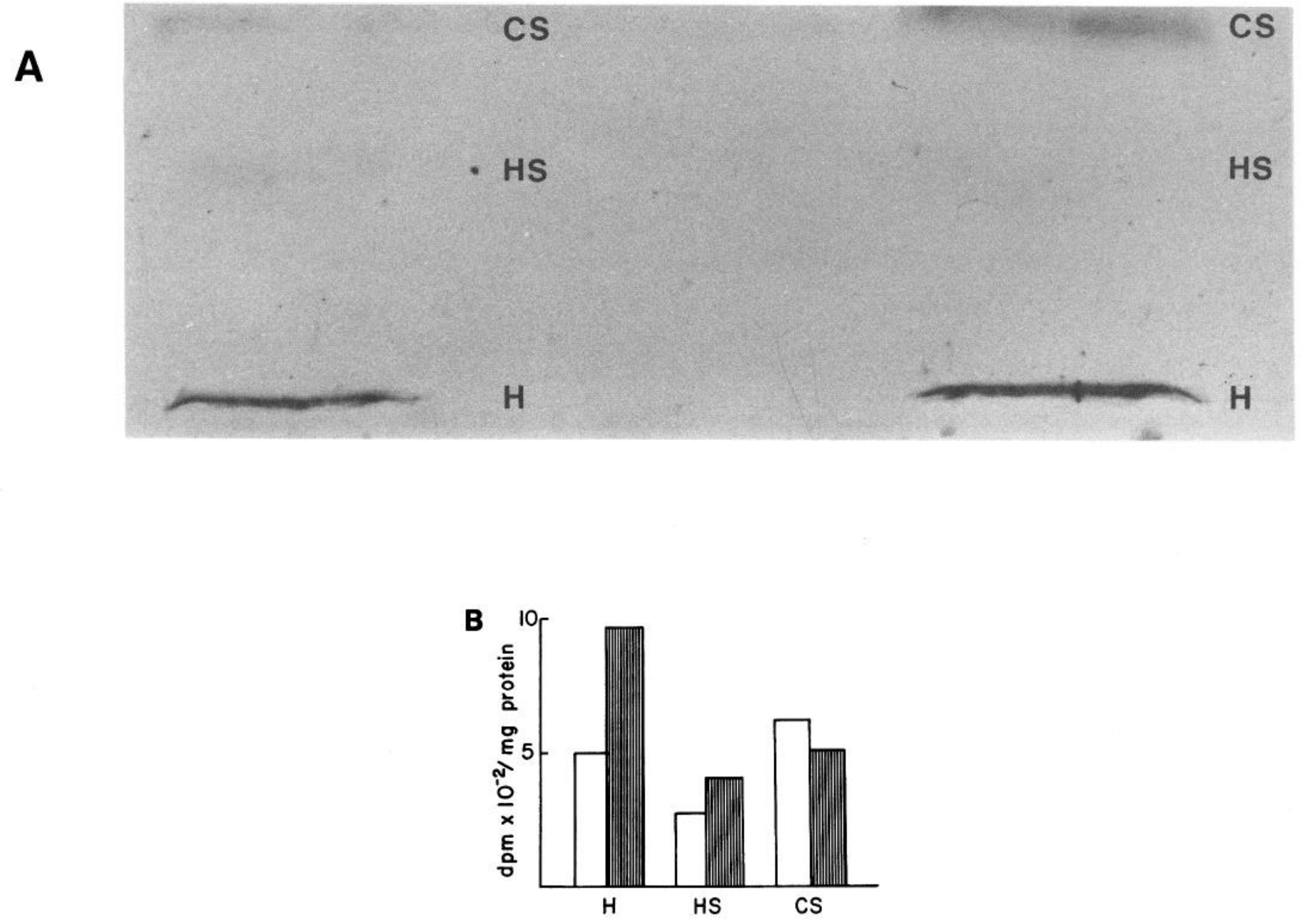

Figure 1. Cellulose acetate electrophoresis of glycosaminoglycans. $A$, Radioautograph of glycosaminoglycans (GAGs) isolated from spinal cord neurons (left lane) and conditioned medium (right lane). Neurons from a dozen $18 \mathrm{~mm}$ wells and their conditioned medium were used in the GAG isolation. The mobility of a standard mixture of GAGs is shown: $H$, heparin; $H S$, heparan sulfate; $C S$, chondroitin sulfate. $B$, GAGs isolated from DRG neurons (open bars) and DRG neuron-conditioned medium (filled bars). Results are expressed as dpm $\times 10^{-2} / \mathrm{mg}$ cellular protein.

clonal rabbit antilaminin $(1: 200)$ and antifibronectin $(1: 100)$ were added to culture wells in a total volume of $10 \mu \mathrm{l}$ at the time neurons were seeded. In some experiments, HNK-1 (Leu 7) and P3X control ascites fluid were overlaid on the laminin substrate for $6-8 \mathrm{hr}$ and then removed prior to seeding of neurons. Plates were incubated at $4^{\circ} \mathrm{C}$ for $30 \mathrm{~min}$ in the upright position, then at $4^{\circ} \mathrm{C}$ for $30 \mathrm{~min}$ in the inverted position, followed by incubation in the inverted position at $37^{\circ} \mathrm{C}$ in a humidified atmosphere of $5 \% \mathrm{CO}_{2}$ and air for the remainder of the assay. Wells were examined at $200 \times$ magnification under phase optics at various times between 3 and $24 \mathrm{hr}$, and the number of cells with processes greater than 2 cell diameters was counted.

To assay for substrate-attached neurite-promoting activity in conditioned medium and the effect of enzyme digestion on this activity, chondroitinase $\mathrm{ABC}$ and heparitinase digestions of conditioned medium were carried out as described previously, and $10 \mu \mathrm{l}$ of medium was then added to Terasaki microwells previously coated sequentially with poly(Dlysine) and laminin. After an overnight incubation at $4^{\circ} \mathrm{C}$, the medium was removed, the wells washed thoroughly, and DRG neurons added in serum-free defined medium with 4 pM NGF. Wells were scored for process formation as described above.

Survival assay. After neurons were scored for process formation, some experimental wells were analyzed for survival of adherent cells. MTT (dimethylthiazol-2-yl-2,5-diphenyltetrazolium bromide), $1 \mu \mathrm{l}$, was added to each well to give a final concentration of $0.5 \mathrm{mg} / \mathrm{ml}$. The plates were incubated for $30 \mathrm{~min}\left(37^{\circ} \mathrm{C}, 5 \% \mathrm{CO}_{2}\right)$, and the wells were scored using bright-field optics for tetrazolium blue-positive cells. MTT is converted by viable mitochondria to a blue tetrazolium precipitate and has been used as a sensitive indicator of neuronal cell survival (Dow and Riopelle, 1985).

Statistical analysis. Differences between groups were compared by Student's $t$ test or analysis of variance and the method of least-significant difference (Snedecor and Cochran, 1980).

\section{Results}

\section{Biosynthesis of proteoglycans by neurons}

Spinal cord conditioning cultures were highly enriched for neurons as early as $24 \mathrm{hr}$ after exposure to cytosine arabinoside. Greater than $90 \%$ of spinal cord cells reacted positively with anti-NF160, but no labeling with anti-GAL-C or anti-GFAP was observed at $48 \mathrm{hr}$, the time of labeling with ${ }^{35} \mathrm{~S}$-sulfate. Thus, the probability that spinal cord neurons were responsible for proteoglycan synthesis and release was high. Similarly, DRG 


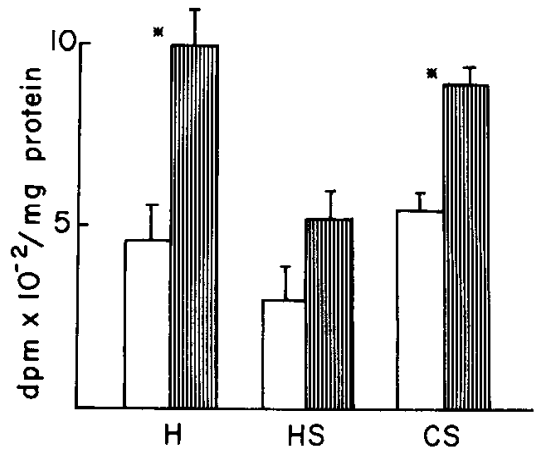

Figure 2. Effect of $\beta$-D-xyloside on glycosaminoglycan synthesis. GAGs were isolated from conditioned medium produced in the absence (open bars) and presence ( filled bars) of $\beta$-D-xyloside and separated by cellulose acetate electrophoresis. Results are expressed as $\mathrm{dpm} \times 10^{-2} / \mathrm{mg}$ cellular protein (mean $\pm \mathrm{SD}, n=3$ ). GAGs with the mobility of $\mathrm{H}$ and $\mathrm{CS}$ produced in the presence of $\beta$-D-xyloside were significantly increased above control levels $\left({ }^{*} p<0.01\right)$.

cultures were highly enriched for neurons by $24 \mathrm{hr}$ and devoid of non-neuronal cells by $48 \mathrm{hr}$.

\section{Cellulose acetate electrophoresis}

High-density cultures enriched for either sensory or spinal cord neurons were labeled continuously with ${ }^{35} \mathrm{~S}$-sulfate from day 2 to day 7 of culture. When GAGs were extracted from the cells or from the conditioned medium and subjected to cellulose acetate electrophoresis, bands comigrating with heparin $(\mathrm{H})$, heparan sulfate (HS), and chondroitin sulfate (CS) standards were detected by radioautography. Heavily labeled bands with the mobility of $\mathrm{CS}$ and $\mathrm{H}$ were seen in medium conditioned by ${ }^{35}$ S-sulfate-labeled spinal cord neurons (Fig. $1 \mathrm{~A}$, right lane). A faint band with the mobility of HS was also detected. Using cell extracts of spinal cord neurons, the most heavily labeled band had the mobility of $\mathrm{H}$, but $\mathrm{HS}$ and $\mathrm{CS}$ could also be detected (Fig. 1 $A$, left lane). A similar pattern of bands comigrating with $\mathrm{H}, \mathrm{HS}$, and CS standards was seen with DRG neurons and neuron-conditioned medium when the cellulose acetate plate was scraped for scintillation counting (Fig. 1B).

\section{$\beta$ - $D$-Xyloside co-incubation}

To examine more directly the synthesis of GAGs by neurons, high-density, neuron-enriched spinal cord preparations were cultured with ${ }^{35} \mathrm{~S}$-sulfate in the absence and presence of $0.2 \mathrm{~mm}$ $\beta$-D-xyloside. Medium from neurons cultured in the presence of $\beta$ - $\mathrm{-}$-xyloside contained more total GAG-containing molecules as measured by the CPC filter assay (conditioned control medium, $232 \pm 65 \mathrm{dpm} / 100 \mu \mathrm{l}$; conditioned $\beta$-D-xyloside medium, $791 \pm 133 \mathrm{dpm} / 100 \mu \mathrm{l} ; n=5, p<0.01$ ). As demonstrated by cellulose acetate electrophoresis and scintillation counting of the scraped plates (Fig. 2), an increase above control occurred in GAGs with the mobility of $\mathrm{H}$ and $\mathrm{CS}(p<0.01)$.

\section{Enzyme digestions}

The identity of released GAGs was further characterized by the CPC filter assay using ${ }^{35} \mathrm{~S}$-sulfate-labeled neuron-conditioned medium digested with heparitinase $(350 \mathrm{mU} / \mathrm{ml})$ or chondroitinase $\mathrm{ABC}(100 \mathrm{mU} / \mathrm{ml})$. Following heparitinase digestion of conditioned medium, $64 \pm 17 \%$ of control counts remained bound to the CPC-impregnated filter disk, while following chondroitinase $\mathrm{ABC}$ digestion, $45 \pm 14 \%$ of control counts remained.

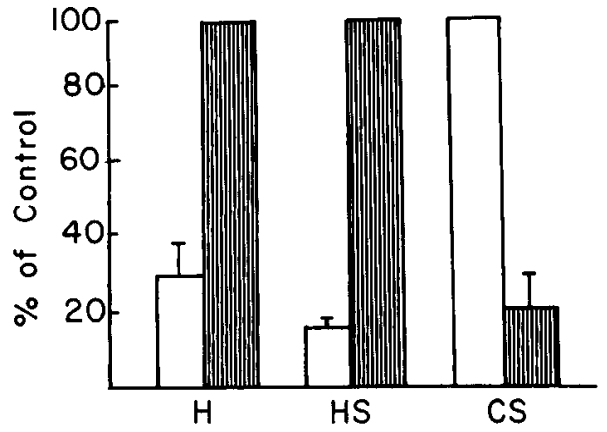

Figure 3. Effect of enzyme digestion of glycosaminoglycans separated by cellulose acetate electrophoresis. Enzyme digestions were carried out on GAGs isolated from conditioned medium. Heparitinase (open bars) and chondroitinase $\mathrm{ABC}$ (hatched bars) were used under the conditions indicated in Materials and Methods. Results are expressed as means \pm $\mathrm{SD}(n=4)$ of percent of control.

A more definitive identification of GAGs was performed by enzyme digestion of isolated GAGs followed by cellulose acetate electrophoresis. Chondroitinase ABC digestion of GAGs isolated from neuron-conditioned medium resulted in a loss of radioactivity in a band migrating with the mobility of CS on cellulose acetate, with no influence on bands with mobility of $\mathrm{H}$ and HS (Fig. 3). Heparitinase had a specific effect on a HS standard but resulted in a loss of radioactivity of bands comigrating with $\mathrm{H}$ and $\mathrm{HS}$ standards. These findings suggest that the band comigrating with the $\mathrm{H}$ standard was a highly sulfated HS, which is in keeping with the known heterogeneity of charge of this GAG (Gallagher and Walker, 1985).

SDS-PAGE and radioautography of dialyzed, lyophilized aliquots of ${ }^{35} \mathrm{~S}$-sulfate-conditioned media revealed a single band at the top of the stacking gel, the mobility of which was less following heparitinase and chondroitinase digestion (Fig. 4). Enzymatic digestion of ${ }^{3} \mathrm{H}$-leucine-conditioned medium had no effect on the density of the proteins detected by radioautography. Thus, no significant proteolytic activity was present in the chondroitinase or heparitinase enzyme preparations.

\section{Neurite-promoting activity of proteoglycans}

Inverted well assay to quantify process formation

In the present studies, attempts were made to eliminate nonspecific adhesion of neurons that might confound scoring of assays. Similar approaches have been used previously with nonneuronal cells (Dennis et al., 1982, 1984). Neurons were permitted to adhere for only $30 \mathrm{~min}$ at $4^{\circ} \mathrm{C}$, following which plates were inverted for the remainder of the assay. Thus, scoring of assays made use of cells that adhered within $30 \mathrm{~min}$ and extended processes via interactions with the substrate of growth exceeding a force of $1 \times g$.

On a laminin substrate, sensory neurons adhere and extend processes independent of the presence of NGF (Baron-Von Evercooren et al., 1982). NGF was used in the present studies to accelerate the rate of regenerative ncuritc outgrowth, thus facilitating quantification in short-term assays. The number of neurons used for the present assays was deliberately kept low to minimize cell-cell interactions. As a routine, approximately 500-900 neurons were seeded. After 20-24 hr with plates in the inverted position, approximately $7-10 \%$ of the seeded cells had processes, but this number represented in excess of $85 \%$ of the total adherent cells.

Assays were scored by counting the total number of neurons 


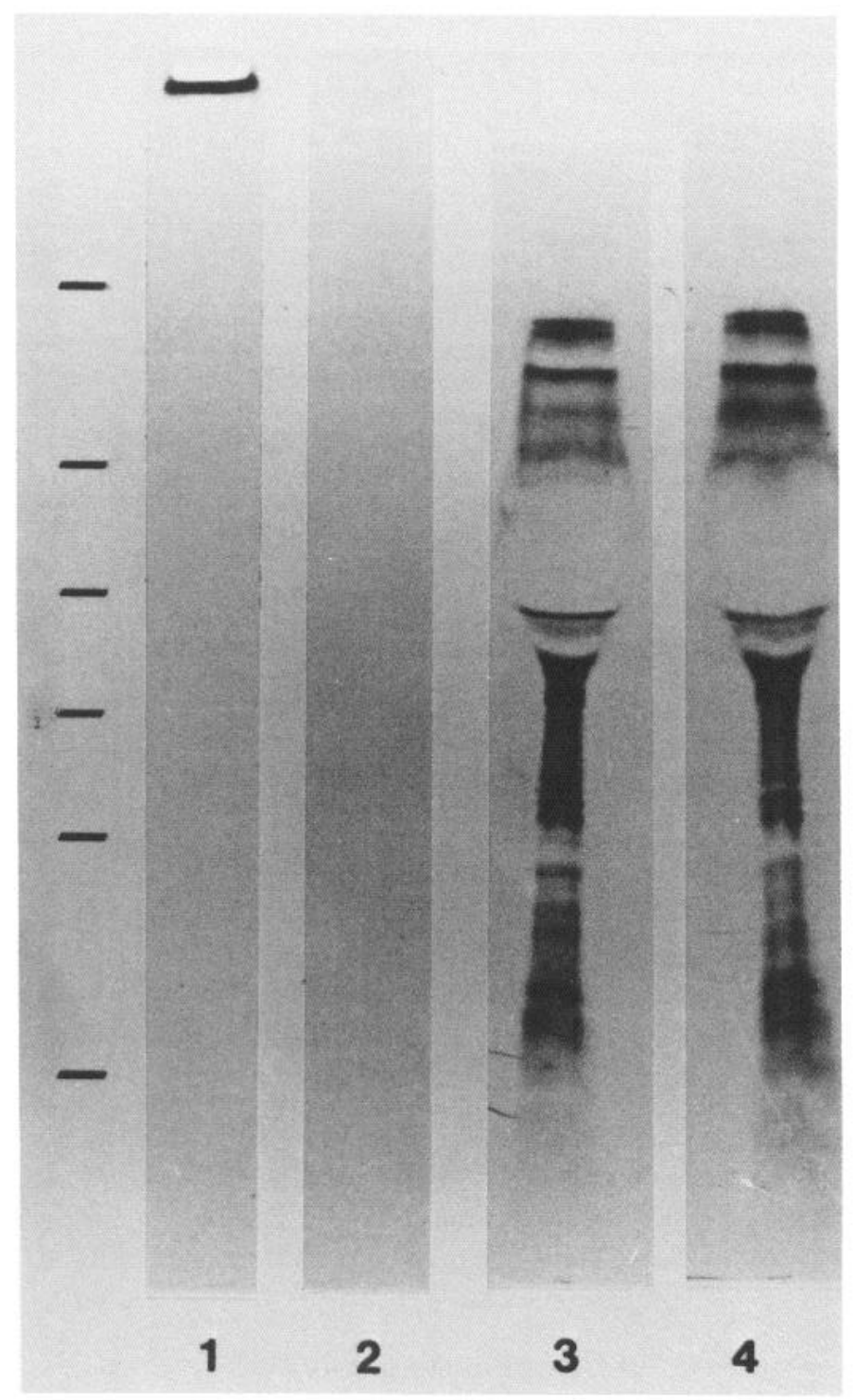

Figure 4. SDS-PAGE of ${ }^{35} \mathrm{~S}$-sulfate and ${ }^{3} \mathrm{H}$-leucine-conditioned media. Lanes 1 and $2,{ }^{35}$ S-sulfate-labeled medium; lanes 3 and $4,{ }^{3} \mathrm{H}$ leucine-labeled medium. Lanes 1 and 3 are controls; lanes 2 and 4 are digested with chondroitinase $\mathrm{ABC}$ followed by heparitinase. The markers at left represent the position of molecular-weight standards (from top to bottom: $200,92,69,46,30,14 \mathrm{kDa}$ ).

in the wells with processes longer than 2 cell diameters. This method of quantification underestimated the influence of inhibitory effects since in these wells both the number of neuritebearing cells and the length of the processes were less than in control wells.

\section{Influence of neuron-conditioned medium on neurite formation-effects of enzyme digestion}

Medium from high-density spinal cord neuron cultures was used to pretreat the laminin substrate overnight at $4^{\circ} \mathrm{C}$. Wells were then washed extensively prior to seeding of sensory neurons in defined medium with NGF. At $20 \mathrm{hr}$, neurite extension was at least twice that seen on laminin treated with control defined medium ( $p<0.001$; Fig. 5, $A, B)$. Where the poly(D-lysine) substrate was pretreated with conditioned medium and then by laminin, neurite outgrowth was never enhanced more than $15 \%$

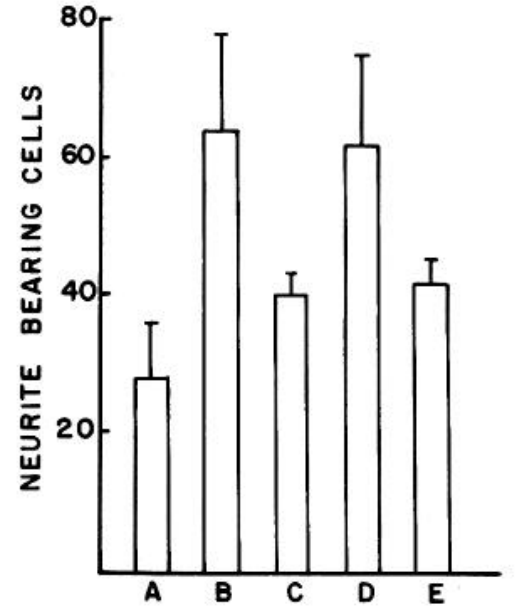

Figure 5. Influence of pretreatment of a laminin substrate with neuronconditioned medium on process formation by DRG neurons. The laminin substrate was treated with $(A)$ control medium, $(B)$ conditioned medium exposed to conditions for heparitinase digestion without addition of enzyme, $(C)$ conditioned medium previously digested with heparitinase $\left(350 \mathrm{mU} / \mathrm{ml}\right.$, for $1 \mathrm{hr}$ at $\left.43^{\circ} \mathrm{C}\right),(D)$ conditioned medium previously digested with chondroitinase $\mathrm{ABC}(100 \mathrm{mU} / \mathrm{ml}$, for $1 \mathrm{hr}$ at $37^{\circ} \mathrm{C}$ ), or $(E)$ conditioned medium previously digested with chondroitinase $A B C$ followed by heparitinase. After pretreatment $\left(24 \mathrm{hr}, 4^{\circ} \mathrm{C}\right)$, the wells were washed thoroughly and freshly dissociated DRG neurons (800-900/well) were added in serum-free defined medium with 4 pM NGF. The inverted well assay was used as described in Materials and Methods, and wells were scored for process formation after $20 \mathrm{hr}$ in culture. Results are expressed as means $\pm \operatorname{SD}(n=6)$ of the number of neurite-bearing cells per well.

above control, suggesting that factors in the conditioned medium bound to laminin afforded maximal effect on neurite outgrowth. Where the conditioned medium had been digested previously with heparitinase, the difference between laminin treated with control medium and laminin treated with conditioned me-

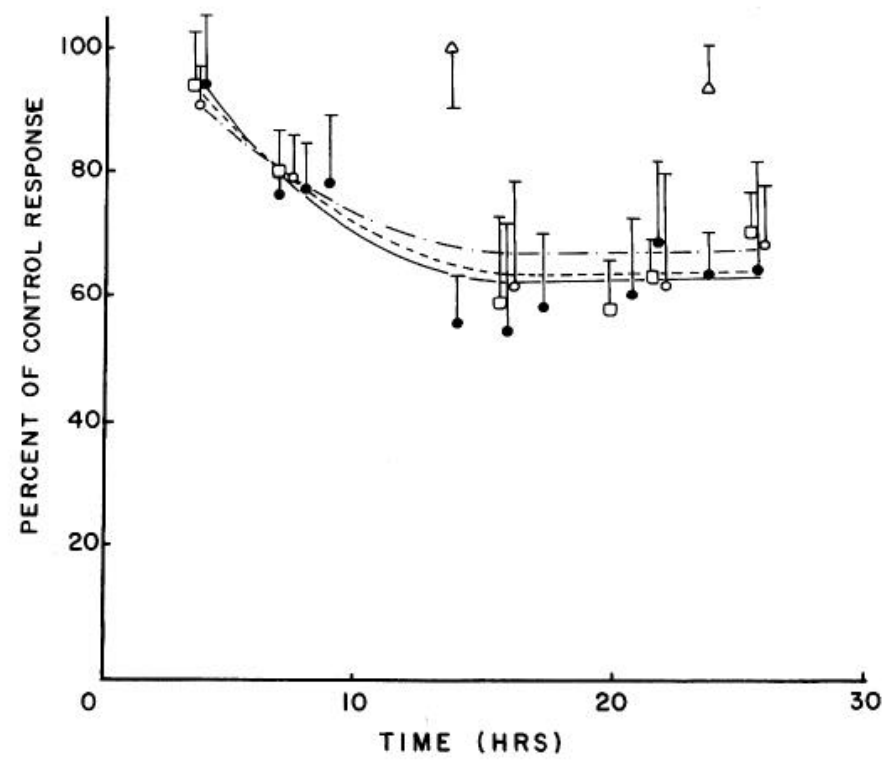

Figure 6. Kinetics of $\beta$-D-xyloside inhibition of neurite formation and the influence of HNK-1 (Leu 7). Data are expressed as means $\pm \mathrm{SD}(n$ $=10$ ) of percent of control (4-methylumbelliferyl- $\beta$-D-glucoside, $1 \mathrm{mM}$, $+\mathrm{P} 3 \mathrm{X}, 10 \mu \mathrm{g} / \mathrm{ml}$ ) response; triangles refer to survival; squares, $\beta$-Dxyloside (1 mM) control; open circles, HNK-1 (Leu 7) $(10 \mu \mathrm{g} / \mathrm{ml})$ control; closed circles, $\beta$-D-xyloside, HNK-1 (Leu 7). 

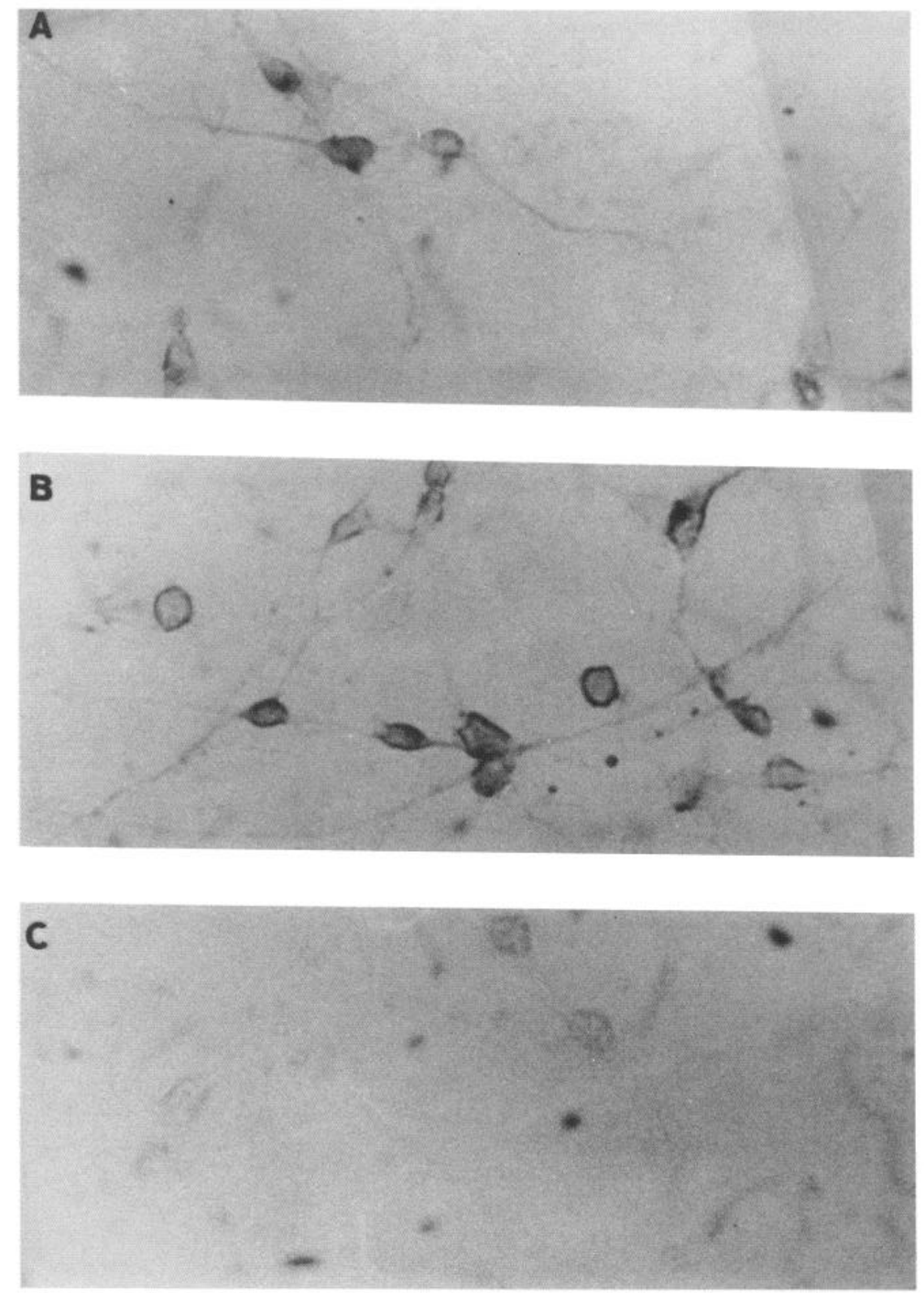

Figure 7. Bright-field photomicrographs of sensory neurons following immunocytochemical labeling at $24 \mathrm{hr}$ in vitro. $A$, HNK-1 (Leu 7) $1: 40 ; B$, GEN-S3, 1:40; $C$, control (P3X) ascites, 1:40. Alkaline phosphatase-conjugated goat anti-mouse immunoglobulins (heavy and light chains) were used at $1: 1500 . \times 320$. dium was insignificant (Fig. 5, A, C). A confounding variable of a heparitinase effect on laminin was excluded by exposing the laminin substrate to heparitinase in conditioned medium overnight at $4^{\circ} \mathrm{C}$. Chondroitinase digestion of conditioned medium (Fig. 5D) had no influence on neurite-promoting activity, and the effects of sequential chondroitinase and heparitinase digestions were no different than that of heparitinase digestion alone (Fig. 5, $C, E$ ).

\section{Influence of $\beta-D$-xyloside on neurite formation}

In the presence of $1 \mathrm{~mm} \beta$-D-xyloside, the number of neuritebearing cells at $4 \mathrm{hr}$ was no different than in control cultures with 4-methylumbelliferyl- $\beta$-D-glucoside (Fig. 6, boxes), and the influence of $\beta$-D-xyloside was no different at $0.2,1$, and $2 \mathrm{~mm}$ (data not shown). At $20 \mathrm{hr}$, however, there were significantly fewer neurons with processes than in control wells.

To examine the kinetics of $\beta$-D-xyloside inhibition more rigorously, sensory neurons prepared as described were co-incu- bated with saturating concentrations of laminin $(5 \mu \mathrm{g} / \mathrm{ml})$ without or with $1 \mathrm{mM} \beta$-D-xyloside, and neurite formation was counted at various times up to $26 \mathrm{hr}$ of incubation. In the presence of $\beta$-D-xyloside there was inhibition of neurite outgrowth, and the time to half-maximal saturation of the effect was approximately $8 \mathrm{hr}$ (Fig. 6, boxes). At times longer than 14 $\mathrm{hr}$ there were approximately $40 \%$ more neurite-bearing cells in the absence of $\beta$-D-xyloside than in the presence of this inhibitor $(p<0.001)$.

\section{Biological effects of monoclonal antibodies}

Figure 7 shows labeling of sensory neurons with HNK-1 (Leu 7) $(A)$ and GEN-S3 $(B)$. All 3 monoclonal antibodies to peptide fragments of MAG (GEN-S1, GEN-S3, GEN-S8) labeled virtually $100 \%$ of sensory neuron cell bodies and processes in vitro. Similarly, the HNK-1 (Leu 7) monoclonal antibody labeled both cell bodies and processes of the neurons. Controls showed minimal reaction product on cell bodies and none on processes $(C)$. 


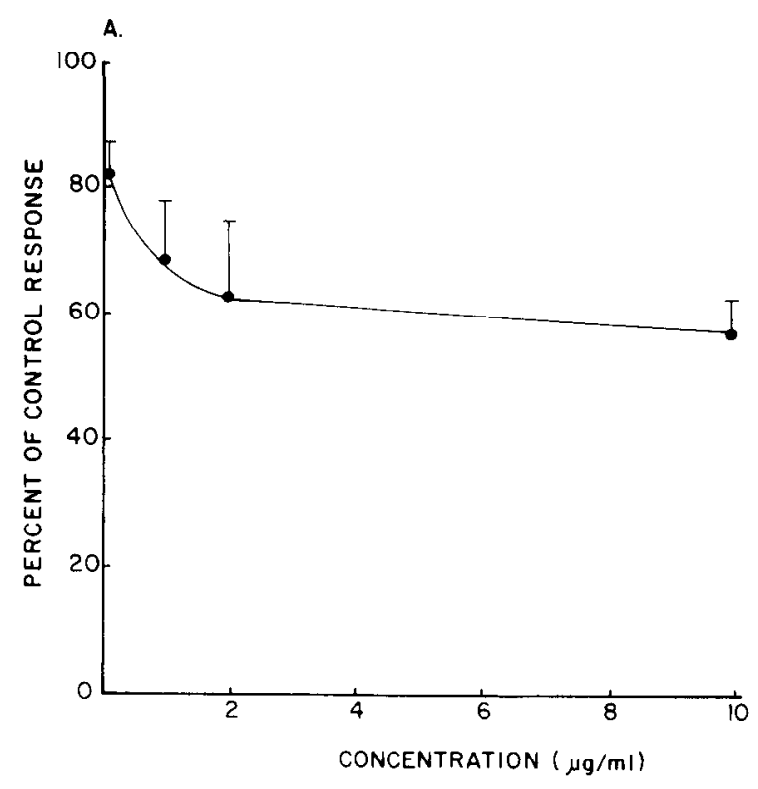

8.

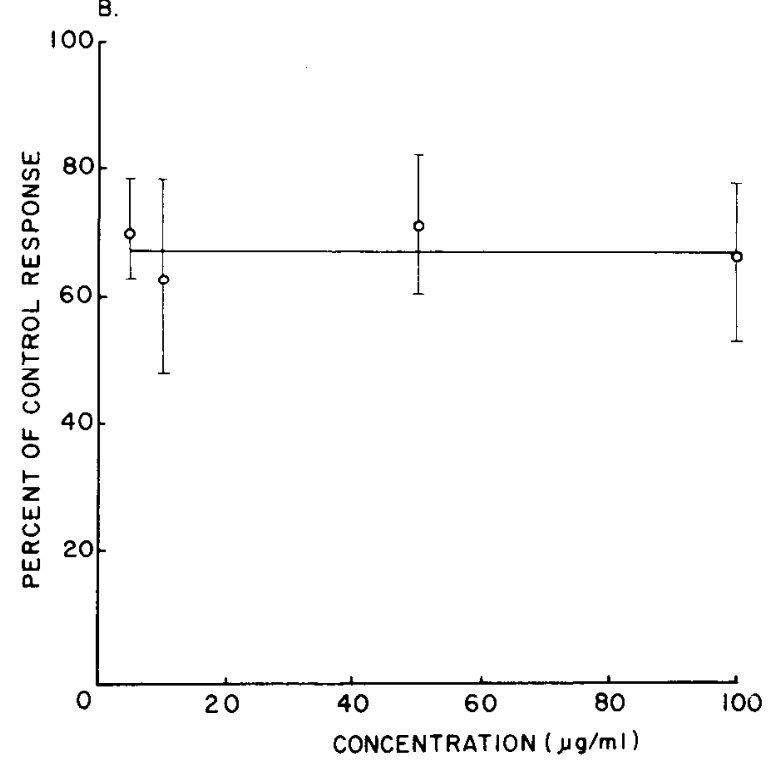

Figure 8. Influence of HNK-1 (Leu 7) on DRG cell neurite formation at $16 \mathrm{hr}$ on a laminin substrate. $A$, Concentration dependence of inhibition by HNK-1 (Leu 7), where the poly(D-lysine) substrate was coated with $5 \mu \mathrm{g} / \mathrm{ml}$ laminin. $B$, Inhibition by $10 \mu \mathrm{g} / \mathrm{ml} \mathrm{HNK}-1$ (Leu 7), where various concentrations of laminin were used to coat the poly(D-lysine) substrate. Results are expressed as means $\pm \operatorname{SD}(n=12)$ of percent of control response [in the presence of $\mathrm{P} 3 \mathrm{X}$ at concentrations identical to those used for HNK-1 (Leu 7)].

beling of neurons by HNK-1 (Leu 7) has been reported previously (McGarry et al., 1985).

\section{Influence of HNK-1 (Leu 7)}

In the presence of HNK-1 (Leu 7), sensory neurons adhered to laminin, but at 16-24 hr they displayed reduced neurite formation that was dependent upon the concentration of HNK-1 (Leu 7) (Fig. 8A). The influence of the monoclonal antibody had plateaued at $40-50 \%$ inhibition between $5-10 \mu \mathrm{g} / \mathrm{ml}$ compared with control (P3X). At the saturation concentration of $10 \mu \mathrm{g} /$ $\mathrm{ml}$, the inhibitory effect of HNK-1 (Leu 7) on process formation was not dependent upon the concentration of laminin used to treat the poly(D-lysine) substrate of growth: the percentage inhibition by HNK-1 (Leu 7) was reasonably constant over 2 log orders of laminin concentration between 1 and $100 \mu \mathrm{g} / \mathrm{ml}$ (Fig. $8 B$ ).

Inhibition of neurite outgrowth by HNK-1 (Leu 7) was significant $(p<0.001)$ and specific for this monoclonal antibody; inhibition was observed only if the antibody was co-incubated with the neurons (Table 1). At $16.5 \mathrm{hr}$, the 3 monoclonal antibodies to peptide domains of the cell adhesion molecule MAG (GEN-S1, GEN-S3, and GEN-S8) failed to inhibit neurite formation at $10 \mu \mathrm{g} / \mathrm{ml}$ (Table 1) or at $50 \mu \mathrm{g} / \mathrm{ml}$. Control ascites fluid (P3X) had no effect on neurite extension. Antibody to laminin inhibited process formation by sensory neurons by 90 $95 \%$ but also markedly decreased cell adhesion. Antibody to fibronectin had no effect.

For studies of the kinetics of HNK-1 (Leu 7) inhibition, saturating concentrations of $\mathrm{HNK}-1$ (Leu 7$)(10 \mu \mathrm{g} / \mathrm{ml})$ and laminin $(5 \mu \mathrm{g} / \mathrm{ml})$ were used. At $3-4 \mathrm{hr}$ after seeding of neurons, there was no inhibition of neurite formation by HNK-1 (Leu 7). However, by 7-9 hr, inhibition could be detected and was highly significant ( $p<0.001$ ); this effect plateaued between $15-24 \mathrm{hr}$ (Fig. 6, closed circles). Thus, the time to half-maximal inhibition by HNK-1 (Leu 7) was approximately 7-8 hr. During the time that inhibition was maximal and plateaued, there was no significant effect of HNK-1 (Leu 7) on cell adherence or the survival of adherent cells (Fig. 6, triangles).

\section{Influence of $H N K-1$ (Ieu 7) and $\beta-D$-xyloside co-incubations}

Since the kinetics and magnitude of inhibition of neurite outgrowth by $\beta$-D-xyloside and HNK-1 (Leu 7) were similar, coincubation studies were carried out to determine if the influence of HNK-1 (Leu 7) was mediated through blockade of neuronal interaction with released, laminin-complexed proteoglycan species. Sensory neurons were co-incubated on laminin with saturating concentrations of $\beta$-D-xyloside ( $1 \mathrm{~mm}$ ) and HNK-1 (Leu 7) $(10 \mu \mathrm{g} / \mathrm{ml})$, and neurite outgrowth was examined at various times from 4 to $26 \mathrm{hr}$. The kinetics and magnitude of inhibition of neurite outgrowth in the presence of HNK-1 (Leu 7 ) and $\beta$-D-xyloside were no different than that observed when either of the additives was used alone (Fig. 6).

Influence of enzyme digestion of neuron-conditioned medium on HNK-1 (Leu 7) inhibition of neurite outgrowth

Mcdium from scnsory ncuron cultures harvested after $7 \mathrm{~d}$ exposure to the cells and having a titer of at least 32 trophic units (reciprocal of the dilution giving half-maximal stimulation of neurite formation) was plated onto a laminin substrate overnight at $4^{\circ} \mathrm{C}$. Wells were then washed extensively prior to seeding of sensory neurons. As early as $3-3.5 \mathrm{hr}$, the number of neuritebearing cells on the treated laminin was $60-70 \%$ greater than on laminin alone in the presence of control ascites fluid or monoclonal antibodies GEN-S1, GEN-S3, or GEN-S8 $(p<$ $0.01)$. By $20 \mathrm{hr}$, the difference between treated and untreated laminin was less obvious but in the range of $50 \%$. At all times, but most marked for times up to $8 \mathrm{hr}$, processes of neurons on treated laminin were longer than on laminin alone. However, in the presence of HNK-1 (Leu 7), the inhibition that was maximal only after $14 \mathrm{hr}$ on untreated laminin (Fig. 6), was maximal from the earliest times $(3-4 \mathrm{hr}$ ) when laminin was pretreated with sensory neuron-conditioned medium (Fig. 9, inset). 
Table 1. Modulation of DRG neuron process formation on laminin ${ }^{\alpha}$

\begin{tabular}{lc} 
Addition & $\begin{array}{c}\text { Percentage of } \\
\text { control response } \\
\text { (means } \pm \text { SD) }\end{array}$ \\
\hline P3X $(10 \mu \mathrm{g} / \mathrm{ml})$ & $100 \pm 17$ \\
HNK-1 $(\mathrm{Leu} 7)(10 \mu \mathrm{g} / \mathrm{ml})$ & $58 \pm 13^{c}$ \\
HNK-1 $(\mathrm{Leu} 7)(10 \mu \mathrm{g} / \mathrm{ml})^{b}$ & $97 \pm 8$ \\
GEN-S1 $(10 \mu \mathrm{g} / \mathrm{ml})$ & $100 \pm 3$ \\
GEN-S3 $(10 \mu \mathrm{g} / \mathrm{ml})$ & $93 \pm 11$ \\
GEN-S8 $(10 \mu \mathrm{g} / \mathrm{ml})$ & $101 \pm 4$ \\
Antilaminin $(1: 200)$ & $5^{d}$ \\
Antifibronectin $(1: 100)$ & $94 \pm 10$ \\
\hline
\end{tabular}

a $16.5 \mathrm{hr}$ assay.

${ }^{b} 8 \mathrm{hr}$ preincubation on laminin substrate.

c $p<0.001(n=12)$.

${ }^{d}$ Decreased adhesion.

To provide further evidence that inhibition of neurite formation by HNK-1 (Leu 7) occurred via blockade of neuronproteoglycan interactions, spinal cord neuron-conditioned medium previously digested with heparitinase or chondroitinase was used to pretreat the laminin substrate. Chondroitinase treatment had no influence on the inhibitory effect of HNK-1 (Leu 7) on pretreated laminin at $4 \mathrm{hr}$. However, heparitinase digestion removed the enhanced neurite-promoting activity of pretreated laminin and the inhibitory effect of HNK-1 (Leu 7) $(p<0.001$; Fig. 9).

\section{Discussion}

\section{Biosynthetic studies}

The present studies suggest that peripheral and central neurons in vitro synthesize and release heterogeneous species of proteoglycans. Proteoglycans are recovered in cell extracts and in the tissue culture medium: the latter finding suggests a release of these species by the neurons to the extracellular environment.

While a potential small contribution to the proteoglycans detected by radioisotopic and biological studies in conditioned medium from non-neuronal cells contaminating the high-density cultures cannot be eliminated completely, studies of singleneuron performance in short-term assays in the presence of an inhibitor of proteoglycan assembly suggest a role for HSPGs in neurite extension and provide unequivocal evidence that sensory neurons are a source of this class of proteoglycans.

Using cellulose acetate electrophoresis it was apparent that the proteoglycans were heterogeneous. Glycosaminoglycans with the same mobility as CS, HS, and $\mathrm{H}$ standards were extracted from cells and from conditioned medium. The identity of the ${ }^{35} \mathrm{~S}_{-} \mathrm{SO}_{4}$-labeled band migrating with a $\mathrm{CS}$ standard was confirmed as chondroitin sulfate on the basis of chondroitinase digestion; this treatment had no influence on bands migrating with $\mathrm{H}$ or HS standards. While mobility on cellulose acetate suggested that both heparin and heparan sulfate proteoglycans were produced, this was not confirmed by digestion with a degradative enzyme specific for $\mathrm{HS}$. Bands migrating with both $\mathbf{H}$ and HS standards were reduced in intensity following digestion of conditioned medium with heparitinase, but this enzyme had no influence on bands migrating with a CS standard. The interpretation of these data is that neurons synthesize a family of HSPGs differing in charge densities. This finding is not unique

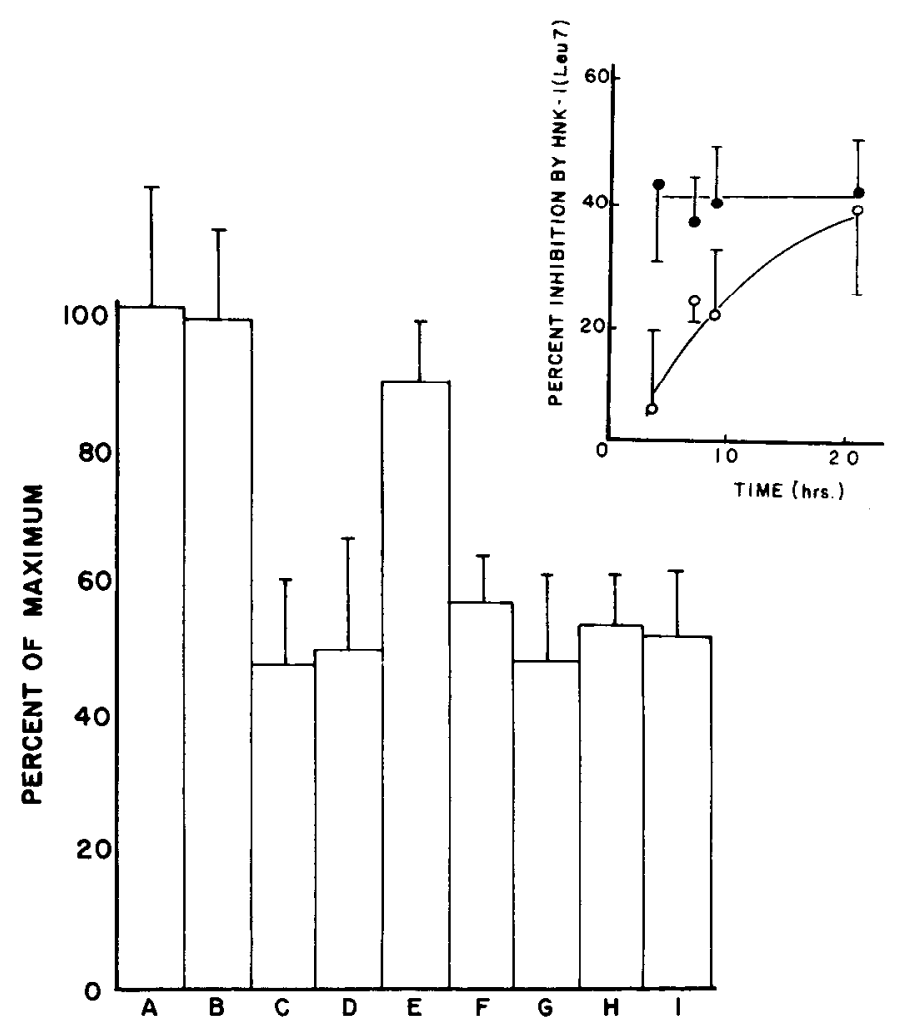

Figure 9. Influence of pretreatment of a laminin substrate with spinal cord neuron-conditioned medium; influence of heparitinase and chondroitinase digestion on HNK-1 (Leu 7) inhibition of neurite outgrowth at $4 \mathrm{hr}$. Spinal cord neuron-conditioned medium was digested with heparitinase $(F, H)$ or chondroitinase $(B, D)$ or exposed to the same conditions without addition of enzyme $(A, C, E, G)$. Medium not exposed to cells but placed on tissue culture wells for the same time period was used as control $(I)$. Wells were exposed to the various treated media overnight at $4^{\circ} \mathrm{C}$, and sensory neurons were seeded in fresh defined medium with $10 \mu \mathrm{g} / \mathrm{ml} \mathrm{HNK}-1$ (Leu 7) or control (P3X) ascites fluid $(10 \mu \mathrm{g} / \mathrm{ml})$. Assays were scored at $4 \mathrm{hr}$. Data are expressed as means \pm $\mathrm{SD}(n=6)$ of percent of maximum. $A$, Chondroitinase control plus P3X; $B$, chondroitinase plus $\mathrm{P} 3 \mathrm{X}$; $C$, chondroitinase control plus HNK-1 (Leu 7); $D$, chondroitinase plus HNK-1 (Leu 7 ); $E$, heparitinase control plus $\mathrm{P} 3 \mathrm{X} ; F$, heparitinase plus $\mathrm{P} 3 \mathrm{X} ; G$, heparitinase control plus HNK-1 (Leu 7); $H$, heparitinase plus HNK-1 (Leu 7); and $I$, control medium. Inset, Time course of inhibition of DRG cell neurite formation by 10 $\mu \mathrm{g} / \mathrm{ml}$ HNK-1 (Leu 7). Open circles refer to the untreated laminin substrate; closed circles, to laminin pretreated with conditioned medium. Results are expressed as means $\pm \operatorname{SD}(n=12)$ of percent inhibition by HNK-1 (Leu 7).

to neurons, similar observations having been made with other cell systems (Gamse et al., 1978; Winterbourne et al., 1983; Gallagher and Walker, 1985).

The assembly and display of proteoglycans by neurons appear to be similar to that described for other neural cells in vitro (Matthew and Patterson, 1984; Matthew et al., 1985). These studies used immunological techniques to detect HSPGs released into tissue culture medium and cell-bound HSPG removed by protease digestion. In the prescnt biosynthctic studics, proteoglycans were both cell-associated and released into the extracellular milieu. There appeared to be no qualitative differences in the electrophoretic profiles of cell-bound and released species, and both cell-bound and released GAGs behaved similarly in the presence of $\beta$-D-Xyloside. $\beta$-D-Xyloside inhibits as- 
sembly of GAGs onto the protein core by acting as a competitive substrate for the galactosyl transferase required for the synthesis of the linkage region of the oligosaccharide chain (Robinson et al., 1975; Beeley, 1986), and therefore an increase in free GAG chains would be anticipated in the presence of excess $\beta$-D-Xyloside. This obscrvation was made when the ncurons werc incubated with ${ }^{35} \mathrm{~S}_{-} \mathrm{SO}_{4}$ in the presence of $\beta$-D-xyloside and monitored by both the CPC filter assay and by cellulose acetate electrophoresis. Of interest, however, and in agreement with studies using the Englebreth-Holm-Swarm (EHS) tumor line, exposure to $\beta$-D-xyloside produced preferentially HS GAG-chains of high degrees of sulfation (Ledbetter and Hassell, 1986).

The present studies extend earlier observations on CNS production of proteoglycans. Proteoglycans of the CS and HS class have been extracted from whole brain during development (Margolis et al., 1975); extracellular labeling of CS was detected in granular and molecular cell layers of neonatal rat cerebellum, and intracellular labeling of astrocytes appeared at a somewhat later stage (Aquino et al., 1984). While the developmental profile of some proteoglycans has been established, the identity of cells producing the proteoglycans has not been elucidated completely. The present findings suggest that one source of proteoglycans in the CNS is neurons. Both CS and HS can be found and the HS species appears to be a heterogeneous family with different charge densities possibly related to both size and degrees of sulfation.

\section{Biological studies}

The functional studies presented here indicate that neuronal HSPGs are endowed with neurite-promoting activity. These functional assays provide data at the single cell level that directly support the biosynthetic studies suggesting synthesis and release of HSPGs. Laminin is known to have a HSPG binding domain on its long arm in juxtaposition to the neurite formation site (Timpl et al., 1983; Edgar et al., 1984; Engvall et al., 1986). Neurite formation by sensory neurons on a laminin substrate was inhibited by $\beta$-D-xyloside but not by the inactive 4 -methylumbelliferyl- $\beta$-D-glucoside (Carey et al., 1987). The effect of $\beta$-D-xyloside developed with a half-time of $7-8 \mathrm{hr}$ and was saturated between 0.2 and $2 \mathrm{~mm}$ : Over this range of concentrations, neuronal proteoglycan-induced Schwann cell proliferation was inhibited by $90 \%$ (Ratner et al., 1985) and enhanced GAG synthesis by EHS tumor cells was constant (Ledbetter and Hassell, 1986). The observations that inhibition of neurite outgrowth in the presence of $\beta$-D-xyloside was significant at times greater than $14 \mathrm{hr}$ but not present at $4 \mathrm{hr}$ and that 4 -methylumbelliferyl- $\beta$ $D$-glucoside had no effect suggest either that neurite formation at times less than $4 \mathrm{hr}$ was unrelated to an interaction of neurons with newly synthesized and released laminin-complexed proteoglycans or that these proteoglycans were insufficient to promote neurite outgrowth. The finding that the inhibitory effect of $\beta$-D-xyloside developed with a half-time of 7-8 hr and was maximal at times greater than $14 \mathrm{hr}$ is consistent with neuronal synthesis, assembly, and release of proteoglycans to the extracellular milieu. While the experiments demonstrating an inhibitory effect of $\beta$-D-xyloside on neurite formation indicated that released neurite-promoting activity contained proteoglycans, the indirect studies with neuron-conditioned medium suggested that HSPGs were the class of proteoglycans endowed with this activity. Conditioned medium that had becn predigested with heparitinase was unable to stimulate neurite outgrowth at a level similar to that seen when untreated, or chondroitinase-digested conditioned medium was used to pretreat the laminin substrate. This effect was not due to influences of the enzyme on the laminin substrate.

\section{Neuron-HSPG interaction}

Studies with the monoclonal antibody HNK-1 (Leu 7) have been interpreted to suggest that the interaction of neurons with HSPGs complexed to laminin is mediated by a site at or in juxtaposition to the HNK-1 (Leu 7) epitope on the neuronal cell surface.

A number of observations have led to these conclusions. Inhibition of process formation on laminin by HNK-1 (Leu 7) could not be explained by a direct influence on the neuronlaminin interaction. If the inhibition were due to a direct influence, it should have been significant from earliest times, and less inhibition should have been seen with increasing concentrations of laminin. First, the time-dependent appearance of inhibition of process formation by HNK-1 (Leu 7) observed in the present studies would not be expected if the inhibition were directed at the neuron-laminin interaction unless the HNK-1 (Leu 7) epitope were not present on the cell surface at early times. In earlier studies (McGarry et al., 1985), the neuronal HNK-1 (Leu 7) epitope was reconstituted on the cell surface within the $3 \mathrm{hr}$ preplating period used to prepare neurons for the assays. Furthermore, pretreatment of laminin with neuronconditioned medium resulted in the appearance of inhibition from the earliest times (Fig. 9, insert), indicating by a functional assay the presence of the HNK-1 (Leu 7) epitope. Second, even though saturating concentrations of HNK-1 (Leu 7) were used, inhibition of neurite extension was independent of the concentration of laminin used to coat the culture wells over a range from 1 to $100 \mu \mathrm{g} / \mathrm{ml}$. Although the relationship of substratebound laminin to the concentration used is not known, the finding that inhibition of process formation by HNK-1 (Leu 7) was approximately the same at all laminin concentrations would not be expected if laminin and HNK-1 (Leu 7) were competing for the same neuronal receptor. That HNK-1 (Leu 7) did not interact with laminin was demonstrated by the finding that pretreatment of the laminin substrate with HNK-1 (Leu 7) failed to inhibit neurite formation.

There are 3 plausible explanations for the observations that pretreatment of laminin with neuron-conditioned medium enhanced neurite extension and that the inhibitory effect of HNK-1 (Leu 7) appeared in a time-dependent manner. One possibility is that the neurons might have produced an enzyme species that modified laminin in a way that unmasked a binding site and made it accessible to the neuronal receptor at or in juxtaposition to the HNK-1 (Leu 7) epitope. Even though neuron-released proteolytic species have been identified and partially characterized (Kalderon, 1979; Krystosek and Seeds, 1981; Pittman, 1985), this explanation is unlikely for a number of reasons. First, the effect of HNK-1 (Leu 7) inhibition was independent of the concentration of laminin used to treat the wells. Classical enzyme-substrate interactions would not predict this observation. Second, the effect of neuron-conditioned medium on the laminin substrate was similar to the effect seen on poly(D-lysine) in earlier studies (Riopelle and Cameron, 1984; Riopelle et al., 1986). In both cases, HNK-1 (Leu 7) inhibited process formation by approximately the same degree: poly(D-lysine) is not known to be a substrate for proteolytic species released by neurons. Third, the pretreatment of laminin took placc at a temperature $\left(4^{\circ} \mathrm{C}\right)$ that likely would not favor enzymatic modifi- 
cation of the laminin substrate. Finally, laminin is considered to be quite resistant to proteolytic modification (Ott et al., 1982; Engvall et al., 1986).

A second possibility, suggested by Lander et al. (1985), is that molecular species in the neuron-conditioned medium improved the interaction of laminin with its substrate, thus enhancing neurite outgrowth. That neurite outgrowth on substrates treated by laminin and then by conditioned medium was consistently 4-5 times greater than that observed when the substrate was treated by conditioned medium and then by laminin would suggest that enhanced laminin availability could explain only a fraction of the observed effect.

The third possibility, and the most plausible explanation of the observations, is that the neurons produced molecular species that were released to their microenvironment and, when complexed to laminin, promoted neurite outgrowth via a receptor at or close to the cell surface HNK-1 (Leu 7) epitope. The finding that pretreatment of the laminin substrate with conditioned medium from neuron-enriched cultures made the inhibition of process formation by HNK-1 (Leu 7) significant from the earliest times suggested that the material released to the medium by neurons in high-density cultures and the material released onto the laminin substrate during the time that the inhibitory effects of HNK-1 (Leu 7) became obvious were identical.

That both the neurite-enhancing effect and the inhibitory influence of HNK-1 (Leu 7) at $4 \mathrm{hr}$ were abolished when the conditioned medium used to pretreat the laminin substrate was digested with heparitinase indicated that the neurite-promoting activity resided with $H S P G$ and provided one piece of evidence that the neuron-HSPG interaction was mediated by a domain in juxtaposition to the neuronal HNK-1 (Leu 7) epitope. Further evidence for this interaction was furnished by findings that both the kinetics and the magnitude of inhibition of process formation by HNK-1 (Leu 7) and by $\beta$-D-xyloside were similar and were not additive. Thus, the similar time dependency of inhibition of neurite formation by HNK-1 (Leu 7) and by $\beta$-Dxyloside was related to the kinetics of synthesis, assembly, and release of neuron-derived HSPGs. These observations are consistent with the hypothesis that neurons in conditions permitting neurite outgrowth (adherence, temperature) have synthesized and released proteoglycans (HSPGs) that, when bound to laminin, promoted neurite outgrowth mediated by a receptor at or near the HNK-1 (Leu 7) epitope.

While much of the neurite-promoting activity of neuron-conditioned medium can be accounted for by HSPGs, the present studies do not exclude the possibility that other molecular species play some small rolc. Laminin has becn found to be a ncuritcpromoting species of conditioned medium from a variety of cell lines in vitro (Lander et al., 1985). However, a number of observations suggest that laminin is not produced by neurons. First, neuron-conditioned medium enhanced neurite extension on laminin; second, inhibition of neurite extension by HNK-1 (Leu 7) was independent of the concentration of laminin used to treat the substrate; third, immunobloting of conditioned medium following SDS-PAGE using polyclonal antilaminin and antifibronectin revealed no labeling of species that migrated with subunits of laminin or fibronectin standards (data not shown). It remains a possibility that some of the neuron-released materials with neurite-promoting activity were molecular species with properties similar to other extracellular matrix components or to cell adhesion molecules. Immunoblotting studies of neuron-conditioned medium following SDS-PAGE with anti-en- tactin and with HNK-1 (Leu 7) showed no immunoreactivity (data not shown). While the possibility that a HNK-1 (Leu 7)negative CAM-like molecule was playing some role in neurite extension, the observation that most of the biological activity of neuron-conditioned medium could be accounted for by HSPG-neuronal HNK-1 (Leu 7) epitope interactions suggests that any contribution by such species was small and did not involve the neuronal HNK-1 (Leu 7) epitope.

The present experiments indicate that neurite extension on laminin is complex. In previous studies Edgar et al. (1984) and Engvall et al. (1986) have demonstrated that the neurite-promoting site of laminin is localized to the end of the long arm, which is also the site for heparin binding. Engvall et al. (1986) have shown that the neurite-promoting site is different from the heparin-binding domain. The present studies complement and extend these observations by demonstrating, first, that HSPGs of neuronal origin have neurite-promoting activity and, second, that where the neurite-promoting activity of neuronal HSPGs was insufficient $(<4 \mathrm{hr}$ ) or was removed by $\beta$-D-xyloside, heparitinase digestion, or the HNK-1 (Leu 7) monoclonal antibody, laminin continued to promote neurite outgrowth where adhesion to the substrate was not influenced. Thus, laminin was able to promote neurite outgrowth by providing adhesion and neurite-promoting domains and a binding site for HSPGs with neurite-promoting activity.

The finding that HNK-1 (Leu 7) inhibited the neuron-HSPG interaction that promoted neurite outgrowth has begun to elucidate the nature of a neuronal receptor for HSPGs. HNK-1 (Leu 7) recognizes an epitope on the neuronal cell surface (McGarry et al., 1985). This epitope is also present on nervous system glycolipids and gangliosides (Ilyas et al., 1984; Chou et al., 1985). However, on the neuron surface the HNK-1 epitope is trypsin labile and therefore present on protein (McGarry et al., 1985). The epitope has been shown to be a complex carbohydrate (Kruse et al., 1984; McGarry et al., 1985) on cell adhesion glycoproteins (Kruse et al., 1984) and on myelin associated glycoprotein (McGarry et al., 1983). Using chick embryo neurons, immunoblotting studies with HNK-1 (Leu 7) following SDS-PAGE detected glycoproteins spanning a molecular-weight range of 100-300 kDa (McGarry et al., 1985). That monoclonal antibodies to peptide domains expressed on the cell adhesion molecule MAG (Nobile-Orazio et al., 1984) and on sensory neurons did not participate directly in the neuron-HSPG interaction (Table 1) adds further support to the suggestion that the neuronal interaction with HSPGs released by the neurons is mediated by a carbohydrate epitope on cell adhesion glycoprotcins. This interpretation is consistent with the studies of Cunningham et al. (1983) demonstrating a HSPG binding domain on the neural cell adhesion molecule. As pointed out by Schachner and colleagues (Kruse et al., 1984) and Riopelle et al. (1986), the cell adhesion glycoproteins provide neurons with a multiplicity of adhesive mechanisms. The present studies extend previous experiments and add to the list of adhesive properties of cell adhesion glycoproleins by demonstrating that carbohydrate domains at or in juxtaposition to the HNK-1 (Leu 7) epitope of these neuronal glycoproteins interact with laminincomplexed neurite-promoting HSPGs. Parenthetically, that MAG is expressed by sensory neurons remains to be established conclusively using molecular probes for MAG: immunoblotting studies with the GEN-S1 and GEN-S3 monoclonal antibodies following SDS-PAGE of sensory and spinal cord neuron extracts revealed a number of bands spanning a molecular-weight range 
of 90-300 kDa, some of which were also labeled with HNK-1 (Leu 7) (R. J. Riopelle, unpublished observations).

Much remains to be learned of the functional significance of interactions between adhesion glycoproteins and proteoglycans during development or regeneration. Bronner-Fraser (1987) has described a potential role for the HNK-1 (Leu 7) epitope in neural crest development and migration, and Erickson and Turley (1987) have reported that neural crest cells synthesize and release proteoglycans, including HSPG. There is evidence that cell adhesion molecules and proteoglycans play roles in both cell-cell and cell-substrate interactions in vitro (Cole and Glaser, 1986; Cole et al., 1986; Bixby et al., 1987) and that these molecular species are interactive. Observations reported in the present studies indicating that HSPGs have neurite-promoting activity, are both cell bound and released to the extracellular milieu, and display different charge densities suggest a degree of functional diversity of these proteoglycans analogous to that attributed to cell adhesion glycoproteins.

That laminin can promote neurite outgrowth by at least 2 mechanisms and that neurons can modify and respond to modifications of defined molecular species of the extracellular matrix using microheterogeneous interactive molecular species begins to address mechanisms that may subserve selective pathway guidance and exquisite connectivity during axonal growth and regeneration.

\section{References}

Aquino, D. A., R. U. Margolis, and R. K. Margolis (1984) Immunocytochemical localization of a chondroitin sulfate proteoglycan in nervous tissue. II. Studies in developing brain. J. Cell Biol. 99: 11301139.

Baron-Van Evercooren, A., H. K. Kleinman, S. Ohno, P. Marangos, J. P. Schwartz, and M. E. Dubois-Dalcq (1982) Nerve growth factor, laminin, and fibronectin promote neurite growth in human fetal sensory ganglia cultures. J. Neurosci. Res. 8: 179-193.

Beeley, J. G (1986) Radioactive labelling techniques. In Laboratory Techniques in Biochemistry and Molecular Biology-Glycoprotein and Proteoglycan Techniques, R. H. Burdon and P. H. van Knippenberg, eds., p. 417.

Bennett, G. S., S. J. Tapscott, C. DiLullo, and H. Holtzer (1984) Differential binding of antibodies against the neurofilament triplet proteins in different avian neurons. Brain Res. 304: 291-302.

Bixby, J. L., R. S. Pratt, J. Lilien, and L. F. Reichardt (1987) Neurite outgrowth on muscle cell surface involves extracellular matrix receptors as well as $\mathrm{Ca}(2+)$-dependent and -independent cell adhesion molecules. Proc. Natl. Acad. Sci. USA 84: 2555-2559.

Bonner, W. M., and R. A. Laskey (1974) A film detection method for tritium-labelled proteins and nucleic acids in polyacrylamide gels. Eur. J. Biochem. 46: 83-88.

Bottenstein, J. E., S. S. Skaper, S. S. Varon, and G. H. Sato (1980) Selective survival of neurons from chick embryo sensory ganglionic dissociates utilizing serum-free supplemented medium. Exp. Cell Res. 125: 183-190.

Bronner-Fraser, M. (1987) Perturbation of cranial neural crest migration by the HNK-1 antibody. Dev. Biol. 123: 321-331.

Capelletti, R., M. Del Rosso, and V. P. Chiarugi (1979) A new electrophoretic method for the complete separation of all known animal glycosaminoglycans in a monodimensional run. Anal. Biochem. 99 . 311-315.

Carey, D. J., C. M. Rafferty, and M. S. Todd (1987) Effects of inhibition of proteoglycan synthesis on the differentiation of cultured rat Schwann cells. J. Cell Biol. 105: 1013-1021.

Chapman, C. A., B. E. Banks, C. A. Vernon, and J. M. Walker (1981) The isolation and characterization of nerve growth factor from the prostate gland of the guinea-pig. Eur. J. Biochem. 115: 347-351.

Chou, K. H., A. A. Ilyas, J. E. Evans, R. H. Quarles, and F. B. Jungalwala (1985) Structure of a glycolipid reacting with monoclonal IgM in neuropathy and with HNK-1. Biochem. Biophys. Res. Commun. 128: 383-388.
Cole, G. J., and L. Glaser (1986) A heparin-binding domain from $\mathrm{N}$-CAM is involved in neural cell-substratum adhesion. J. Cell Biol. 102: 403-412.

Cole, G. J., A. Loewy, and L. Glaser (1986) Neuronal cell-cell adhesion depends on interactions of N-CAM with heparin-like molecules. Nature 320: $445-447$.

Cunningham, B. A., S. Hoffman, U. Rutishauser, J. Hemperly, and G. M. Edelman (1983) Molecular topography of the neural cell adhesion molecule N-CAM: Surface orientation and location of sialic acidrich and binding regions. Proc. Natl. Acad. Sci. USA 80: 3116-3120.

Dennis, J. W., C. A. Waller, R. Timpl, and V. Schirrmacher (1982) Surface sialic acid reduces attachment of metastatic tumor cells to type IV collagen and fibronectin. Nature 300: 274-276.

Dennis, J. W., C. A. Waller, and V. Schirrmacher (1984) Identification of asparagine-linked oligosaccharides involved in tumor cell adhesion to laminin and type IV collagen. J. Cell Biol. 99: 1416-1423.

Dow, K. E., and R. J. Riopelle (1985) Ethanol neurotoxicity: Effects on neurite formation and neurotrophic factor production in vitro. Science 228: 591-593.

Edgar, D., R. Timpl, and H. Thoenen (1984) The heparin-binding domain of laminin is responsible for its effect on neurite outgrowth and neuronal survival. EMBO J. 3: 1463-1468.

Eldridge, C. F., J. R. Sanes, A. Y. Chiu, R. P. Bunge, and C. J. Cornbrooks (1986) Basal lamina-associated heparan sulphate proteoglycan in the rat PNS: Characterization and localization using monoclonal antibodies. J. Neurocytol. 15: 37-51.

Engvall, E., G. E. Davis, K. Dickerson, E. Ruoslahti, S. Varon, and M. Manthorpe (1986) Mapping of domains in human laminin using monoclonal antibodies: Localization of the neurite-promoting site. $\mathrm{J}$. Cell Biol. 103: 2457-2465.

Erickson, C. A., and E. A. Turley (1987) The effects of epidermal growth factor on neural crest cells in tissue culture. Exp. Cell Res. 169: 267-279.

Gallagher, J. T., and A. Walker (1985) Molecular distinctions between heparan sulphate and heparin. Analysis of sulphation patterns indicates that heparan sulphate and heparin are separate families of N-sulphated polysaccharides. Biochem. J. 230: 665-674.

Gamse, G., H. G. Fromme, and H. Kresse (1978) Metabolism of sulfated glycosaminoglycans in cultured endothelial cells and smooth muscle cells from bovine aorta. Biochim. Biophys. Acta 544: 514528.

Hronowski, L., and T. Anastassiades (1980) Rates of glycosaminoglycan synthesis and rates of incorporation of radioactive precursors into newly synthesized glycosaminoglycan by confluent rat muscle fibroblasts. J. Biol. Chem. 255: 9210-9217.

Ilyas, A. A., R. H. Quarles, and R. O. Brady (1984) The monoclonal antibody HNK-1 reacts with a human peripheral nerve ganglioside. Biochem. Biophys. Res. Commun. 122: 1206.

Kalderon, N. (1979) Migration of Schwann cells and wrapping of neurites in vitro: A function of protease activity (plasmin) in the growth medium. Proc. Natl. Acad. Sci. USA 76: 5992-5996.

Kruse, J., R. Mailhammer, H. Wernecke, A. Faissner, I. Sommer, C. Goridis, and M. Schachner (1984) Neural cell adhesion molecules and myelin-associated glycoprotein share a common carbohydrate moiety recognized by monoclonal antibodies L 2 and HNK-1. Nature 311: 153-155.

Krystosek, A., and N. Seeds (1981) Plasminogen activator release at the neuronal growth cone. Science 213: 1532-1534.

Laemmli, U. K (1970) Cleavage of structural proteins during the assembly of the head of bacteriophage T4. Nature 227: 680-685.

Lander, A. D., D. K. Fujii, and L. F. Reichardt (1985) Purification of a factor that promotes neurite outgrowth: Isolation of laminin and associated molecules. J. Cell Biol. 101: 898-913.

Ledbetter, S. R., and J. R. Hassell (1986) Beta-D-xyloside-mediated alteration in the synthesis of basement membrane proteoglycan. Arch. Biochem. Biophys. 246: 403-410.

Lowry, O. H., N. J. Rosebrough, A. L. Farr, and R. J. Randall (1951) Protein measurement with the folin phenol reagent. J. Biol. Chem. 193: 265-275.

Margolis, R. U., R. K. Margolis, L. B. Chang, and C. Preti (1975) Glycosaminoglycans of brain during development. Biochemistry 14 : $85-88$.

Matthew, W. D., and P. H. Patterson (1984) The production of a monoclonal antibody that blocks the action of a neurite outgrowthpromoting factor. Cold Spring Harbor Symp. Quant. Biol. 48: 625631. 
Matthew, W. D., R. J. Greenspan, A. D. Lander, and L. F. Reichardt (1985) Immunopurification and characterization of a neuronal heparan sulfate proteoglycan. J. Neurosci. 5: 1842-1850.

McGarry, R. C., S. L. Hclfand, R. H. Quarles, and J. C. Roder (1983) Recognition of myelin-associated glycoprotein by the monoclonal antibody HNK-1. Nature 306: 376-378.

McGarry, R. C., R. J. Riopelle, D. E. Frail, A. M. Edwards, P. E. Braun, and J.C. Roder (1985) The characterization and cellular distribution of a family of antigens related to myelin associated glycoprotein in the developing nervous system. J. Neuroimmunol. 10:101-114.

Mobley, W. C., A. Schenker, and E. M. Shooter (1976) Characterization and isolation of proteolytically modified nerve growth factor. Biochemistry 15: 5543-5551.

Nobile-Orazio, E., A. P. Hays, N. Latov, G. Perman, J. Golier, M. E. Shy, and L. Freddo (1984) Specificity of mouse and human monoclonal antibodies to myelin-associated glycoprotein. Neurology 34 : 1336-1342.

Ott, U., E. Odcrmatt, J. Engcl, H. Furthmayr, and R. Timpl (1982) Protease resistance and conformation of laminin. Eur. J. Biochem. 123: $63-72$.

Pittman, R. N. (1985) Release of plasminogen activator and a calciumdependent metalloprotease from cultured sympathetic and sensory neurons. Dev. Biol. 110: 91-101.

Rapraeger, A., and M. Bernfield (1985) Cell surface proteoglycan of mammary epithelial cells: Protease releases a heparan sulfate-rich ectodomain from a putative membrane-anchored domain. J. Biol. Chem. 260: 4103-4109.
Ratner, N., R. P. Bunge, and L. Glaser (1985) A neuronal cell surface heparan sulfate proteoglycan is required for dorsal root ganglion neuron stimulation of Schwann cell proliferation. J. Cell Biol. 101: 744754.

Riopelle, R. J., and D. A. Cameron (1984) Neurite-promoting factors from embryonic neurons. Dev. Brain Res. 15: 265-274.

Riopelle, R. J., R. C. McGarry, and J. C. Roder (1986) Adhesion properties of a neuronal epitope recognized by the monoclonal antibody HNK-1. Brain Res. 367: 20-25.

Robinson, H. C., M. J. Brett, P. J. Tralaggan, D. A. Lowther, and M. Okayama (1975) The effect of D-xylose, beta-D-xylosides and betaD-galactosides on chondroitin sulphate biosynthesis in embryonic chicken cartilage. Biochem. J. 148: 25-34.

Snedecor, G. W., and W. G. Cochran (1980) Statistical Methods, 7th ed., Iowa State University Press, Ames.

Sutter, A., R. J. Riopelle, R. M. Harris-Warrick, and E. M. Shooter (1979) The heterogeneity of nerve growth factor receptors. Prog. Clin. Biol. Rcs. 31: 659-667.

Timpl, R., S. Johansson, V. VanDelden, I. Oberbaumer, and M. Hook (1983) Characterization of protease-resistant fragments of laminin mediating attachment and spreading of rat hepatocytes. J. Biol. Chem. 258: 8922-8927.

Winterbourne, D. J., A. M. Schor, and J. T. Gallagher (1983) Synthesis of glycosaminoglycans by cloned bovine endothelial cells cultured on collagen gels. Eur. J. Biochem. 134: 271-277. 